\title{
Effects of Myxococcus fulvus KYC4048 Metabolites on Breast Cancer Cell Death ${ }^{\mathrm{S}}$
}

\author{
Chayul Lee ${ }^{1 \dagger}$, Sanghyun Park ${ }^{1 \dagger}$, Ikhbayar Ayush ${ }^{2}$, Kyungyun Cho ${ }^{3}$, Sung Soo Kim ${ }^{1,4}$, Insug Kang ${ }^{1,4}$, \\ Wonchae Choe $^{1,4}$, Yoon-Seong Kim ${ }^{1,4,5}$, and Kyung-Sik Yoon ${ }^{1,4 *}$ \\ ${ }^{1}$ Department of Biochemistry and Molecular Biology, School of Medicine, Kyung Hee University, Seoul 02447, Republic of Korea \\ ${ }^{2}$ Department of Biomedical Science, Graduate School, Kyung Hee University, Seoul 02447, Republic of Korea \\ ${ }^{3}$ Myxobacteria Bank, Department of Biotechnology, Hoseo University, Asan 31399, Republic of Korea \\ ${ }^{4}$ Medical Research Center for Bioreaction to Reactive Oxygen Species and Biomedical Science Institute, School of Medicine, Kyung Hee \\ University, Seoul 02447, Republic of Korea \\ ${ }^{5}$ Burnett School of Biomedical Sciences, College of Medicine, University of Central Florida, Orlando, FL 32816, USA
}

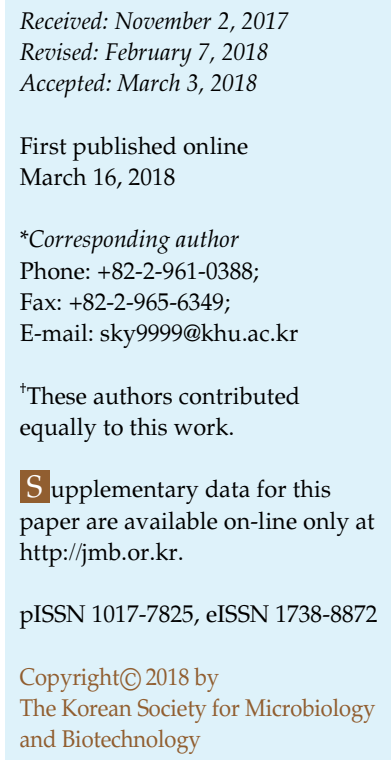

Using MCF7 breast cancer cells, we tested the anticancer activity of metabolites from 130 strains of myxobacteria newly isolated in South Korea. Of these, three strains whose metabolites had high anticancer activity and low cell toxicity were selected and identified by their fruiting body morphology, cell morphology, and 16S rRNA sequence. Strains KYC4030 and KYC4048 were determined to be Myxococcus fulvus, whereas strain KYC4081 was identified as Corallococcus coralloides. We found that metabolites of M. fulvus KYC4048 demonstrated no toxicity in normal cells but specifically induced cancer cell death by suppressing the expression of WNT2B. This discovery highlights the value of assessing the metabolic and biomedical potential of myxobacteria, even those that are already known but were isolated from new areas, and the possible use of metabolites from M. fulvus KYC4048 in cancer treatment.

Keywords: Myxobacteria, WNT2B, anticancer, breast cancer

\section{Introduction}

Myxobacteria, a group of gram-negative soil bacteria belonging to the class Deltaproteobacteria, occur in a variety of habitats such as soil, decaying plant material, rotting wood, and the dung of herbivorous animals. Myxobacteria are classified into 7 families, 22 genera, and 47 species [1, 2], and produce a variety of bioactive secondary metabolites with unique characteristics and cellular effects. More than 500 bioactive substances produced from myxobacteria have been identified, many of which are novel [3-5]. For instance, Sorangium cellulosum produces epothilone [6], a novel anticancer agent that stabilizes microtubules via a taxol-like mechanism of action [6-9]. Notably, a semisynthetic epothilone B analog, ixabepilone, was approved in October 2007 by the United States Food and Drug Administration as a treatment for breast cancer resistant or refractory to currently available chemotherapies $[8,10,11]$. Because of the success of epothilone, research on myxobacterial metabolites has focused mainly on those produced by S. cellulosum. Notably, $48.4 \%$ of myxobacterial species that produce secondary metabolites belong to the genus Sorangium [3]. However, this finding might be due to the enrichment in Sorangium (23.2\%) during the isolation of strains from the wild.

The capacity to produce bioactive metabolites in various myxobacteria was recently confirmed by genomic analysis. For example, gene clusters for the synthesis of 11 bioactive 
polyketide and hybrid polyketide-nonribosomal peptides have been identified in S. cellulosum So ce56 [12, 13], a strain that produces the antibiotics chivosazol and etnangien. Notably, biosynthetic enzyme gene clusters for 18 polyketide and nonribosomal peptides were found in Myxococcus xanthus DK1622 [13, 14], a strain that had been presumed to be unable to produce bioactive substances and had only been used as a model strain to study fruiting body formation and gliding motility. Subsequently, five bioactive molecules were isolated from this strain, using new methods of extraction and culture [13]. Taken together, these data suggest that new bioactive substances can be isolated from myxobacteria, depending on the strain, geographic origin, extraction, and culture conditions.

In this study, we tested the anticancer activity of metabolites from various myxobacterial strains newly isolated from soil in different environmental conditions throughout South Korea. In addition, the effects of these metabolites on genes and proteins associated with cell death were analyzed by RNA sequencing and a Phospho Antibody Explorer Array.

\section{Materials and Methods}

\section{Myxobacterial Culture}

$\mathrm{VY} / 3$ and ST21CX agar media were used to isolate myxobacteria $[15,16]$ and isolates were cultured in CYS liquid media (Table S1) to induce metabolite production as described below. All myxobacterial strains were cultured at $32^{\circ} \mathrm{C}$.

\section{Isolation and Identification of Myxobacteria and Preparation of Metabolites}

Myxobacteria were isolated as previously described [16, 17]. Briefly, soil samples collected throughout South Korea were placed on ST21CX agar plates and incubated at $32^{\circ} \mathrm{C}$ for $2-4$ weeks. Myxobacterial 16S ribosomal RNA (rRNA) genes were amplified using the 5'-GAGTTTGATCCTGGCTGAG-3' (27f) and 5'-AGA AAGGAGGTGATCCAGCC-3' (1525r) primers, as previously reported $[18,19]$. Phylogenetic analysis of the isolates was carried out using ClustalW [20].

For morphologic characterization and identification, the vegetative cells of the myxobacteria grown on $\mathrm{VY} / 3$ agar media were observed using a CKX41 phase-contrast microscope (Olympus, Japan) and the fruiting bodies developed on the VY/3 agar media were observed using an Olympus SZ61 stereomicroscope. The microscopic images were then photographed using an Olympus C-5060 digital camera.

For metabolite preparation, the myxobacteria cells cultured on $\mathrm{VY} / 3$ agar medium and $2 \%$ Amberlite XAD-16 resin (Sigma, USA) were cultured in CYS liquid medium for 7 days at $32^{\circ} \mathrm{C}$ and $180 \mathrm{rpm}$. The resin and cells were extracted twice each with $50 \%$ and $100 \%$ acetone. After the acetone was evaporated from the extract, the resulting residue was dissolved in dimethyl sulfoxide (DMSO, D4540; Sigma, USA) at a concentration of $0.4 \mathrm{~g} / \mathrm{ml}$.

\section{Human Cell Culture and Treatments}

MCF-7 human breast cancer cells were obtained from Seoul National University (Seoul, Korea), whereas MCF10A normal breast cells were purchased from the American Type Culture Collection (USA). MCF-7 cells were grown in RPMI-1640 medium (HyClone, UK) containing 10\% fetal bovine serum (HyClone, UK). MCF10A cells were grown in Dulbecco's modified Eagle's medium/ Ham's F-12 Nutrient Mixture (Gibco, USA) containing 5\% horse serum (Gibco, USA), $2 \mathrm{mM}$ L-glutamine, $10 \mu \mathrm{g} / \mathrm{ml}$ insulin, $0.1 \mu \mathrm{g} / \mathrm{ml}$ cholera toxin, $0.5 \mu \mathrm{g} / \mathrm{ml}$ hydrocortisone, and $20 \mathrm{ng} / \mathrm{ml}$ recombinant human epidermal growth factor. Cells were cultured at $37^{\circ} \mathrm{C}$ in a humidified incubator with $5 \%(\mathrm{v} / \mathrm{v}) \mathrm{CO}_{2}$.

Cell viability was determined based on the conversion of 3-(4,5dimethylthiazol-2-yl)-2,5-diphenyltetrazolium bromide (MTT) to formazan crystals by mitochondrial enzymes. Cells were seeded in 12-well plates at $2 \times 10^{5}$ cells/well in growth medium and cultured to approximately $60-70 \%$ confluency. The cells were then treated with metabolites at concentrations of $0.5 \times\left(10^{2} \mu \mathrm{g} / \mathrm{ml}\right), 1 \times$ $\left(2 \times 10^{2} \mu \mathrm{g} / \mathrm{ml}\right), 2 \times\left(4 \times 10^{2} \mu \mathrm{g} / \mathrm{ml}\right)$, and $5 \times\left(10^{3} \mu \mathrm{g} / \mathrm{ml}\right)$. Subsequently, the media were carefully removed and DMSO $(300 \mu \mathrm{l})$ was added to solubilize the blue formazan crystals in the living cells. Absorbance was measured at $540 \mathrm{~nm}$ using an ELISA reader (Multiskan EX; Thermo Lab Systems, USA).

Flow Cytometry and Annexin V-Fluorescein Isothiocyanate (FITC)/Propidium Iodide (PI) Double Staining

To measure apoptosis, human cells were seeded at $2 \times 10^{5}$ cells $/ \mathrm{ml}$ in 100-mm dishes, cultured for 1 day, and treated for $72 \mathrm{~h}$ with $2 \times 10^{2} \mu \mathrm{g} / \mathrm{ml}$ myxobacterial metabolite. Cells were then harvested, washed with phosphate-buffered saline (PBS), fixed at $4^{\circ} \mathrm{C}$ for $24 \mathrm{~h}$ with ice-cold $75 \%$ ethanol, and pelleted by centrifugation. Subsequently, the cells were washed with PBS, treated for $30 \mathrm{~min}$ with $0.5 \mu \mathrm{g} / \mathrm{ml}$ RNase A in PI buffer, and stained for $30 \mathrm{~min}$ in the dark with $20 \mu \mathrm{g} / \mathrm{ml}$ PI. Cell cycle distribution was then analyzed on the basis of the DNA content using Kaluza flow cytometry software (Beckman Coulter, USA). Apoptosis was also quantified by flow cytometry on the basis of annexin V-FITC and PI double staining. Briefly, human cells exposed to myxobacterial metabolites were trypsinized, collected by centrifugation, resuspended in annexin V-FITC binding buffer, and incubated for $15 \mathrm{~min}$ at room temperature $\left(20-25^{\circ} \mathrm{C}\right)$ in the dark with $1 \mu \mathrm{g} / \mathrm{ml}$ annexin V-FITC and $10 \mu \mathrm{g} / \mathrm{ml}$ PI. Samples were analyzed as described above, using Kaluza flow cytometry software.

\section{RNA Sequencing and Transcript Analysis}

Total RNA was prepared, using QIAzol Lysis Reagent (Qiagen, The Netherlands), from MCF-7 and MCF10A cells grown and treated as described above.

To construct cDNA libraries, $1 \mu \mathrm{g}$ of total RNA was used. The 
Table 1. Strains of myxobacteria producing anticancer metabolites and their activities.

\begin{tabular}{|c|c|c|c|c|c|}
\hline Strain & Genus & Species & $\begin{array}{c}\text { MCF7 }^{\mathrm{a}} \text { cell } \\
\text { viability }(\%)\end{array}$ & Geographic origin & $\begin{array}{l}\text { MCF10A cell } \\
\text { viability (\%) }\end{array}$ \\
\hline KYC4048 & Myхососсиs & fulvus & $27.5 \pm 8.5$ & Changwon, Gyeongsangnam-do & $98.2 \pm 8.5$ \\
\hline KYC4081 & Corallococcus & coralloides & $48.5 \pm 11.5$ & Cheongju, Chungcheongbuk-do & $92.0 \pm 9.1$ \\
\hline KYC4030 & Myхососсиs & fulvus & $69.0 \pm 3.0$ & Sancheong, Gyeongsangnam-do & $93.3 \pm 5.3$ \\
\hline KYC4060 & Myхососсиs & xanthus & $66.0 \pm 6.0$ & Changwon, Gyeongsangnam-do & $88.0 \pm 4.0$ \\
\hline KYC4106 & Myхососсиs & virescens & $48.5 \pm 6.5$ & Eumseong, Chungcheongbuk-do & $70.0 \pm 5.7$ \\
\hline KYC3526 & Sorangium & cellulosum & $64.0 \pm 5.0$ & Cheongdo, Gyeongsangbuk-do & $85.0 \pm 3.5$ \\
\hline KYC4013 & Myхососсиs & stipitatus & $52.0 \pm 7.0$ & Jeju, Jeju-do & $72.0 \pm 6.3$ \\
\hline KYC4014 & Myхососсиs & xanthus & $60.5 \pm 2.5$ & Bonghwa, Gyeongsangbuk-do & $80.0 \pm 7.0$ \\
\hline KYC4103 & Myхососсиs & virescens & $52.0 \pm 4.0$ & Eumseong, Chungcheongbuk-do & $71.0 \pm 8.2$ \\
\hline KYC4075 & Myхососсиs & stipitatus & $51.0 \pm 9.0$ & Seongnam, Gyeonggi-do & $70.0 \pm 8.0$ \\
\hline KYC4065 & Myxococcus & fulvus & $58.0 \pm 3.0$ & Seoul & $76.1 \pm 8.6$ \\
\hline KYC4041 & Myхососсиs & fulvus & $61.0 \pm 2.0$ & Jinju, Gyeongsangnam-do & $79.0 \pm 7.7$ \\
\hline KYC4105 & Myхососсиs & virescens & $16.5 \pm 6.5$ & Eumseong, Chungcheongbuk-do & $32.7 \pm 5.0$ \\
\hline KYC3523 & Sorangium & cellulosum & $74.5 \pm 2.5$ & Yesan, Chungcheongnam-do & $90.0 \pm 3.5$ \\
\hline KYC4028 & Corallococcus & coralloides & $75.0 \pm 2.0$ & Changwon, Gyeongsangnam-do & $87.4 \pm 2.9$ \\
\hline KYC4095 & Corallococcus & coralloides & $83.0 \pm 2.0$ & Paju, Gyeonggi-do & $95.0 \pm 10.0$ \\
\hline KYC4077 & Myхососсиs & fulvus & $59.0 \pm 3.0$ & Seoul & $71.0 \pm 9.0$ \\
\hline KYC4107 & Myхососсиs & fulvus & $46.5 \pm 0.5$ & Eumseong, Chungcheongbuk-do & $55.2 \pm 1.5$ \\
\hline KYC4009 & Myхососсиs & xanthus & $63.0 \pm 1.0$ & Taebaek, Gangwon-do & $65.0 \pm 9.0$ \\
\hline KYC4019 & Myхососсиs & fulvus & $66.5 \pm 5.5$ & Yongin, Gyeonggi-do & $68.3 \pm 8.1$ \\
\hline KYC4066 & Cystobacter & disciformis & $8.5 \pm 0.5$ & Ansan, Gyeonggi-do & $6.6 \pm 8.9$ \\
\hline KYC4050 & Myхососсиs & fulvus & $66.5 \pm 0.5$ & Seoul & $61.9 \pm 3.5$ \\
\hline KYC4102 & Myхососсиs & xanthus & $44.0 \pm 5.0$ & Jinsheon, Chungcheongbuk-do & $21.6 \pm 5.7$ \\
\hline KYC3528 & Sorangium & cellulosum & $52.5 \pm 3.5$ & Cheongyang, Chungcheongnam-do & $26.3 \pm 8.2$ \\
\hline KYC3524 & Sorangium & cellulosum & $59.5 \pm 3.5$ & Haenam, Jeollanam-do & $30.7 \pm 7.5$ \\
\hline KYC4134 & Corallococcus & coralloides & $37.5 \pm 4.5$ & Jinju, Gyeongsangnam-do & $5.8 \pm 2.3$ \\
\hline KYC3527 & Sorangium & cellulosum & $63.0 \pm 0.0$ & Seosan, Chungcheongnam-do & $26.8 \pm 1.9$ \\
\hline KYC4005 & Myхососсиs & xanthus & $74.0 \pm 5.0$ & Gangneung, Gangwon-do & $37.4 \pm 3.9$ \\
\hline KYC3521 & Sorangium & cellulosum & $67.0 \pm 3.0$ & Wando, Jeollanam-do & $30.0 \pm 8.0$ \\
\hline KYC3520 & Sorangium & cellulosum & $61.5 \pm 0.5$ & Gongju, Chungcheongnam-do & $22.4 \pm 5.3$ \\
\hline KYC4011 & Myхососсиs & macrosporus & $82.0 \pm 1.0$ & Jecheon, Chungcheongbuk-do & $34.0 \pm 9.9$ \\
\hline KYC3398 & Sorangium & cellulosum & $85.0 \pm 0.0$ & Busan & $26.9 \pm 2.0$ \\
\hline KYC3522 & Sorangium & cellulosum & $67.0 \pm 5.0$ & Cheonan, Chungcheongnam-do & $5.7 \pm 8.5$ \\
\hline
\end{tabular}

${ }^{\mathrm{a}} \mathrm{MCF} 7$ cell viabilities are presented as the mean $\pm \mathrm{SE}, n=3(p<0.05)$.

mRNA in the total RNA was converted into a library of template molecules suitable for subsequent cluster generation, using the reagents provided in the TruSeq RNA Sample Preparation Kit (Illumina, USA). Briefly, poly-A-containing mRNA molecules were purified using poly-T oligo-attached magnetic beads and the mRNA was fragmented into small pieces using divalent cations under elevated temperature. The cleaved RNA fragments were copied into first-strand cDNA using reverse transcriptase and random primers. This was followed by second-strand cDNA synthesis using DNA polymerase I and RNase $\mathrm{H}$. These cDNA fragments underwent end-repair, single " $\mathrm{A}$ " base addition, and adapter ligation. The products were then purified and enriched by the polymerase chain reaction (PCR) to create the final cDNA library. The libraries were quantified using quantitative (q)PCR according to the $\mathrm{qPCR}$ Quantification Protocol Guide and qualified using an Agilent Technologies 2100 Bioanalyzer (Agilent Technologies, USA).

The RNA-Seq reads were mapped to the human genome using 
TopHat software (ver. 1.3.3), which can report split-read alignments across splice junctions. To estimate expression levels and to find alternatively spliced transcripts, the Cufflinks software (ver. 1.2.1) was applied with default options. The reference genome sequence (hg19, Genome Reference Consortium GRCh37) and annotation data were downloaded from the University of California at Santa Cruz website (http://genome.uscs.edu). The transcript counts at the isoform and gene levels were calculated and the relative transcript abundances were measured in fragments per kilobase of exon per million fragments mapped using Cufflinks.

\section{Western Blot Analysis}

Cells were lysed with radioimmunoprecipitation assay buffer (50 mM Tris- $\mathrm{HCl}, \mathrm{pH} 7.4,150 \mathrm{mM} \mathrm{NaCl}, 5 \mathrm{mM}$ ethylenediaminetetraacetic acid, $0.5 \%$ Na-deoxycholate, $1 \% \mathrm{NP}-40$, and $0.1 \%$ sodium dodecyl sulfate (SDS)) supplemented with protease inhibitors ( $200 \mathrm{mM}$ phenylmethylsulfonyl fluoride, $200 \mathrm{mM} \mathrm{Na}_{2} \mathrm{VO}_{4}$, and $200 \mathrm{mM} \mathrm{NaF}$ ). The cell lysates were separated by SDSpolyacrylamide gel electrophoresis (SDS-PAGE) and proteins were transferred to nitrocellulose membranes (Pall Corporation, USA). The membranes were blocked with blocking buffer (Trisbuffered saline/Tween-20 containing 5\% skim milk) and then incubated with the indicated primary antibodies. $\beta$-Actin (Santa Cruz Biotechnology, USA) was used as loading control. Immunoblots were visualized by enhanced chemiluminescence reagents (Santa Cruz Biotechnology, USA). Quantification of western blots was performed by densitometry using Image J software (National Institute of Health, USA).

\section{Phospho Antibody Explorer Array and Analysis}

Protein extraction was carried out using a protein extraction buffer (Full Moon Biosystems, USA) containing 1\% protease inhibitor cocktail (Sigma, USA), 1\% phosphatase inhibitor cocktail (Sigma, USA), and lysis beads (Full Moon Biosystem, USA). After extraction, the protein solution was purified using the gel matrix column included in the Antibody Array Assay kit. The concentration of the purified sample was measured using the BCA protein assay kit (Pierce, USA) using a NanoPhotometer (Implen, USA) and the purity was confirmed by UV spectrometry. A total of $75 \mu \mathrm{l}$ of labeling buffer was added to each protein sample $(70 \mu \mathrm{g})$, which was then treated with $3 \mu \mathrm{l}$ of a $10 \mu \mathrm{g} / \mu \mathrm{l}$ biotin/dimethylformamide solution. The sample was incubated at room temperature for 90 min with shaking. After incubation, the sample was treated with $35 \mu$ l of stop reagent and incubated at room temperature for 30 min with shaking.

The Phospho Explorer Antibody microarray slide was treated with $30 \mathrm{ml}$ of blocking solution in a petri dish and incubated on a shaker at $55 \mathrm{rpm}$ for $1 \mathrm{~h}$ at room temperature. After blocking, the slide was rinsed with Milli-Q-grade water. The labeled sample was mixed in $6 \mathrm{ml}$ of coupling solution. The blocked array slide was incubated with the coupling mixture on a shaker at $35 \mathrm{rpm}$ for $2 \mathrm{~h}$ at room temperature in a coupling dish. After coupling, the slide was washed six times with $30 \mathrm{ml}$ of washing solution in a petri dish on a shaker at $55 \mathrm{rpm}$ for $5 \mathrm{~min}$. The slides were then rinsed with Milli-Q-grade water. For signal detection, Cy3streptavidin (30 $\mu \mathrm{l}$ of a $0.5 \mathrm{mg} / \mathrm{ml}$ solution; GE Healthcare, UK) was mixed in $30 \mathrm{ml}$ of detection buffer. The coupled array slide was then treated with the detection mixture in a petri dish on a shaker at $55 \mathrm{rpm}$ for $45 \mathrm{~min}$ at room temperature. After detection, the slide was washed six times with $30 \mathrm{ml}$ of washing solution in a petri dish on a shaker at $55 \mathrm{rpm}$ for $5 \mathrm{~min}$, followed by a final rinse in Milli-Q-grade water.

Slide scanning was performed using a GenePix 4000B scanner (Axon Instruments, USA). The slides were completely dried prior to scanning and scanned within $24-48 \mathrm{~h}$. The slides were scanned at $10-\mu \mathrm{m}$ resolution, optimal laser power, and photomultiplier tube voltage. Scanned images were gridded and quantified using GenePix Software (Axon Instruments, USA). The numerical data were analyzed using Genowiz 4.0 (Ocimum Biosolutions, India). After analysis, protein data were annotated using the UniProt database. For each antibody, we computed the following phosphorylation ratio as follows:

$$
\text { Phosphorylation ratio }=\frac{\text { Phospho 2 }- \text { DG }}{\text { Total } 2-\text { DG }} / \frac{\text { Phospho control }}{\text { Total control }}
$$

where phosphorylated and matching unphosphorylated values are denoted by "phospho" and "unphospho" in both the control and experimental data.

\section{Results}

Isolation of Wild Myxobacteria and Determination of the Anticancer Activity and Toxicity of Their Metabolites

We isolated 130 myxobacterial strains from soil samples collected throughout South Korea. Species such as Corallococcus coralloides, Corallococcus exiguous, Myxococcus virescens, M. fulvus, M. xanthus, M. stipitatus, M. macrosporus, S. cellulosum, and Cystobacter disciformis were identified and purified on the basis of their fruiting bodies. Metabolite libraries were then obtained from all 130 strains after induction in CYS medium. The strains identified in this study differed from those isolated in Europe, South America, and China, as strains of the same species typically produce different metabolites in different areas or environments. Metabolites from 33 strains reduced the viability of MCF7 breast cancer cells to less than $85 \%$, and these strains were tested for toxicity in MCF10A normal breast cells. The strains were then listed in order of high anticancer activity and low toxicity (Table 1), and the top three strains were selected for further analysis. This strategy excluded strains such as Cystobacter disciformis KYC4066, which exhibited both very high anticancer activity and cell toxicity and led to viability being reduced to $8.5 \pm 0.5 \%$ in cancer cells and $6.6 \pm 8.9 \%$ in normal cells. 
A
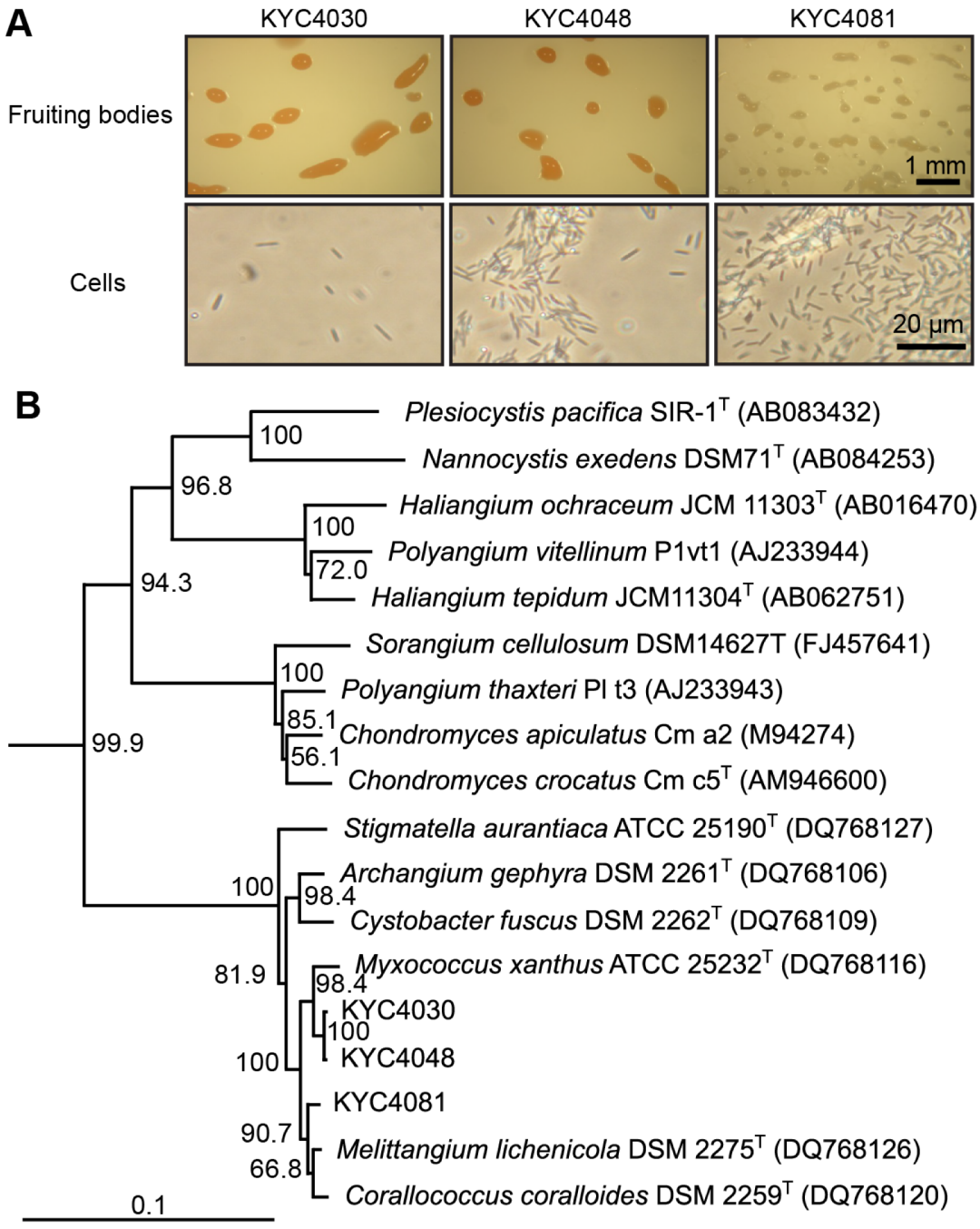

Fig. 1. Morphologic and phylogenetic analyses of myxobacterial strains.

Myxobacterial strains KYC4030, KYC4048, and KYC4081 were selected as producers of metabolites with high anticancer activity and low toxicity. (A) Myxobacterial cells were placed on VY/3 agar plates and incubated at $32^{\circ} \mathrm{C}$ for 7 days to induce the formation of fruiting bodies (upper panels). Vegetative cells were observed by phase-contrast microscopy (lower panels). (B) The phylogenetic tree was constructed using $16 \mathrm{~S}$ rRNA gene sequences. The numbers in parentheses are GenBank accession numbers. Bootstrap support is from 1,000 replicates.

\section{Identification of Selected Strains}

Myxobacteria are usually assigned to a species based on their fruiting body, cell morphology, and 16S rRNA sequence. In culture medium that induces the formation of fruiting bodies, the strains KYC4030 and KYC4048 formed orange hemispheres with $250-500 \mu \mathrm{m}$ diameter, and KYC4081 formed translucent or grey hemispheres with 100-300 $\mu \mathrm{m}$ diameter (Fig. 1A, upper panels). Cells of all strains consisted of bacilli 5-7 $\mu \mathrm{m}$ long (Fig. 1A, lower panels). The 16S rRNA sequence of the strains KYC4030 and KYC4048 was $99.9 \%$ similar to that of strain M. fulvus DSM 16525 (Fig. 1B). KYC4081 was $98.4 \%$ similar to C. coralloides
DSM 2259. Thus, on the basis of their cell morphology, fruiting body morphology, and 16S rRNA sequence, KYC4030 and KYC4048 were classified as M. fulvus and KYC4081 was classified as C. coralloides.

\section{Anticancer Activity and Toxicity of Myxobacteria Metabolites}

Next, we performed additional experiments using the metabolites produced from strains KYC4030 and KYC4048 on MCF7 and MCF10A. We did not further test strain KYC4081 because it did not grow well in the conditions used in our laboratory. The viability of MCF7 breast cancer cells exposed to the metabolites from the KYC4030 and 
KYC4048 metabolites at $0.5 \times(100 \mu \mathrm{g} / \mathrm{ml})$ concentration was $98.3 \pm 0.5 \%$ and $95.1 \pm 0.7 \%$, respectively, and was comparable to that of cells treated with DMSO (100 $\pm 1.3 \%)$. However, the same metabolites had anticancer activity in MCF7 cells at higher concentrations: metabolites from KYC4030 and KYC4048 at the concentration of $5 \times(1 \mathrm{mg} / \mathrm{ml})$ reduced cell viability to $14.2 \pm 1.0 \%$ and $11.0 \pm 0.1 \%$ (Fig. $2 \mathrm{~A}$ ). In contrast, metabolites from KYC4030 and KYC4048 did not affect the viability of normal MCF10A cells for concentrations up to $2 \times(400 \mu \mathrm{g} / \mathrm{ml})$; on the contrary, they seemed to enhance cell viability. At a concentration of $5 \times$ (1 mg/ml), however, KYC4030 and KYC4048 metabolites reduced the viability of MCF10A cells to $42.8 \pm 1.7 \%$ and $42.7 \pm 1.4 \%$, respectively, indicating toxicity when compared with DMSO (83.5 $\pm 5.0 \%$, Fig. 2B). Therefore, we deemed the concentration of $1 \times(200 \mu \mathrm{g} / \mathrm{ml})$ as the optimal metabolite concentration exhibiting anticancer activity and no cellular toxicity.

MCF7 and MCF10A cell viability was then measured over time after exposure to the metabolites (concentration: $1 \times(200 \mu \mathrm{g} / \mathrm{ml})$ metabolites) (Figs. 2C and 2D). At $24 \mathrm{~h}$, the viability of MCF7 cells exposed to KYC4030 and KYC4048 metabolites was $72.4 \pm 2.4 \%$ and $70.7 \pm 4.5 \%$, respectively, whereas that of DMSO-treated cells was $102 \pm 1.4 \%$. The difference in viability increased at 48 and $72 \mathrm{~h}$ post treatment. In particular, cell viability was $33.4 \pm 0.8 \%$ and $16.5 \pm 2.6 \%$ at $72 \mathrm{~h}$ in cells treated with KYC4030 and KYC4048 metabolites, and $152.0 \pm 6.8 \%$ in DMSO-treated cells (Fig. 2C). Conversely, the viability of MCF10A cells was $115.1 \% \pm 10.3 \%$ and $117.4 \% \pm 4.8 \%$, respectively, at $24 \mathrm{~h}$ after treatment with KYC4030 and KYC4048 metabolites, whereas that of DMSO-treated cells was $97.3 \pm 6.3 \%$. Notably, cell viability was higher at 48 and $72 \mathrm{~h}$ in metabolite-treated cells than in DMSO-treated cells (Fig. 2D). Taken together, the data suggest that the anticancer activity of the metabolites increased with time, without a corresponding increase in cell toxicity.

\section{Effects of Myxobacteria Metabolites on Cell Cycle and Apoptosis}

The KYC4030 and KYC4048 metabolites did not affect the cell cycle in normal cells (Fig. 3A, top panels), as measured
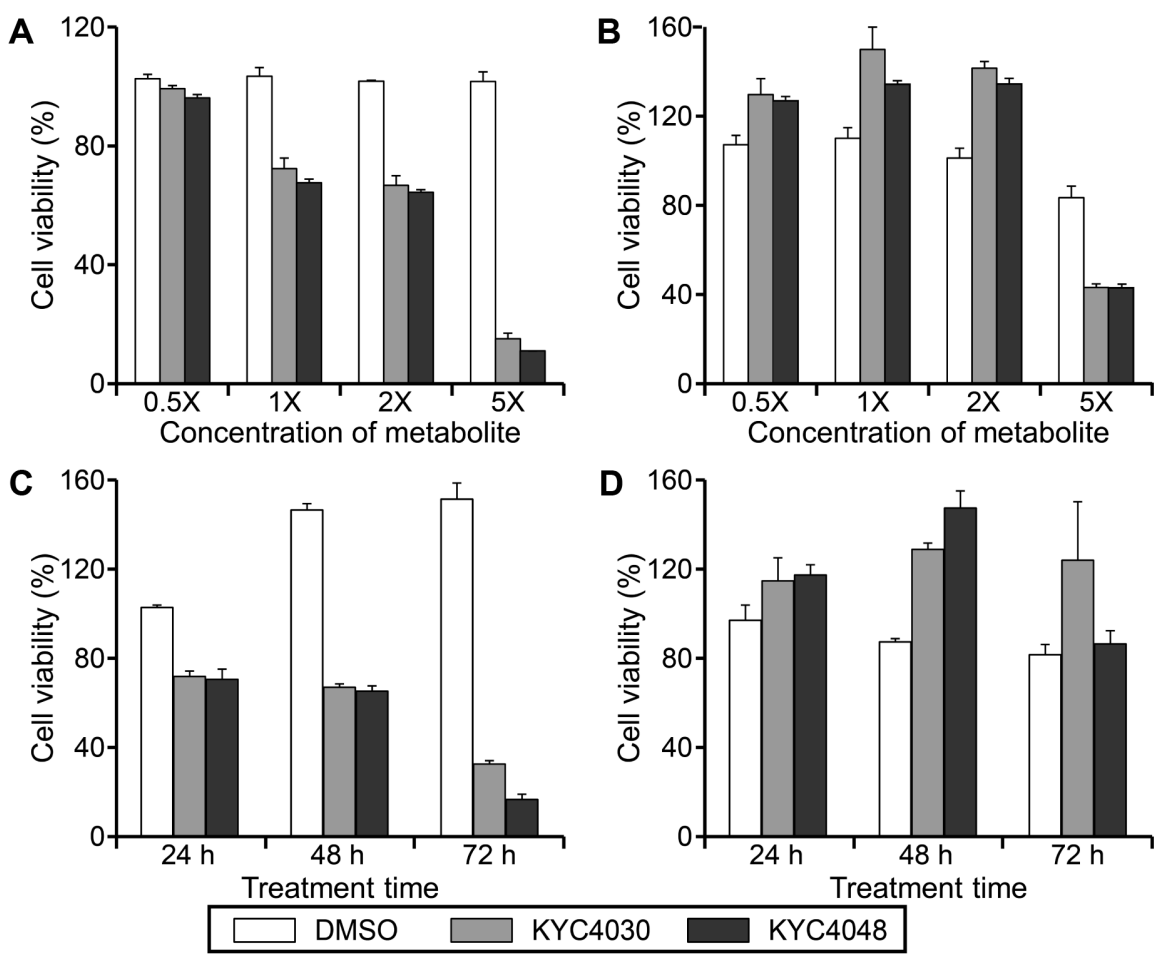

Fig. 2. Dose-dependent anticancer activity measured over time.

The viability of MCF7 (A) and MCF10A (B) cells was determined by MTT assay after treatment with $10^{2}(0.5 \times), 2 \times 10^{2}(1 \times), 4 \times 10^{2}(2 \times)$, and $10^{3}$ $(5 \times) \mu \mathrm{g} / \mathrm{ml}$ KYC4030 or KYC4048 metabolites for $24 \mathrm{~h}$. MCF7 (C) and MCF10A (D) cells were treated with $200 \mu \mathrm{g} / \mathrm{ml}$ metabolites of strains KYC4030 or KYC4048. Controls were treated with the corresponding volume of DMSO. Both MCF7 and MCF10A cells treated with DMSO showed concentration-independent growth. Data are the mean \pm the standard error of at least three experiments. $P<0.05$ vs. cells treated with DMSO at the same concentration. 
by fluorescence-activated cell sorting. In contrast, rapid changes in the cell cycle were observed in breast cancer cells treated with the myxobacterial metabolites (Fig. 3A, center panels). For example, the proportion of cells in subG1, G1, S, and G2/M was 5.7\%, $61.8 \%, 19.0 \%$, and $13.5 \%$, respectively, in DMSO-treated cells, and $43.32 \%, 47.2 \%$,

A

Metabolites treated

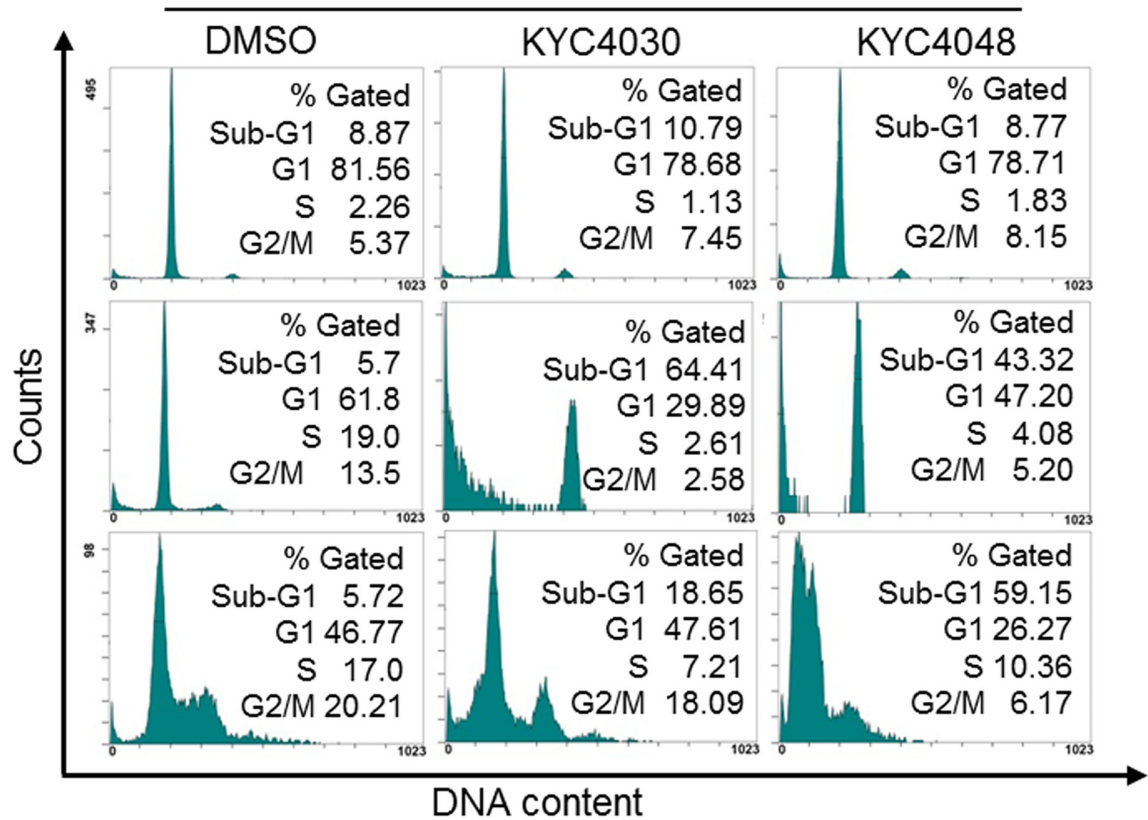

Normal Cells

(MCF10A)

Breast

Cancer Cells

(MCF7)

Neuroblastoma

Cells (SK-N-

$\mathrm{BE}(2)-\mathrm{M} 17$ )

B

Metabolites treated

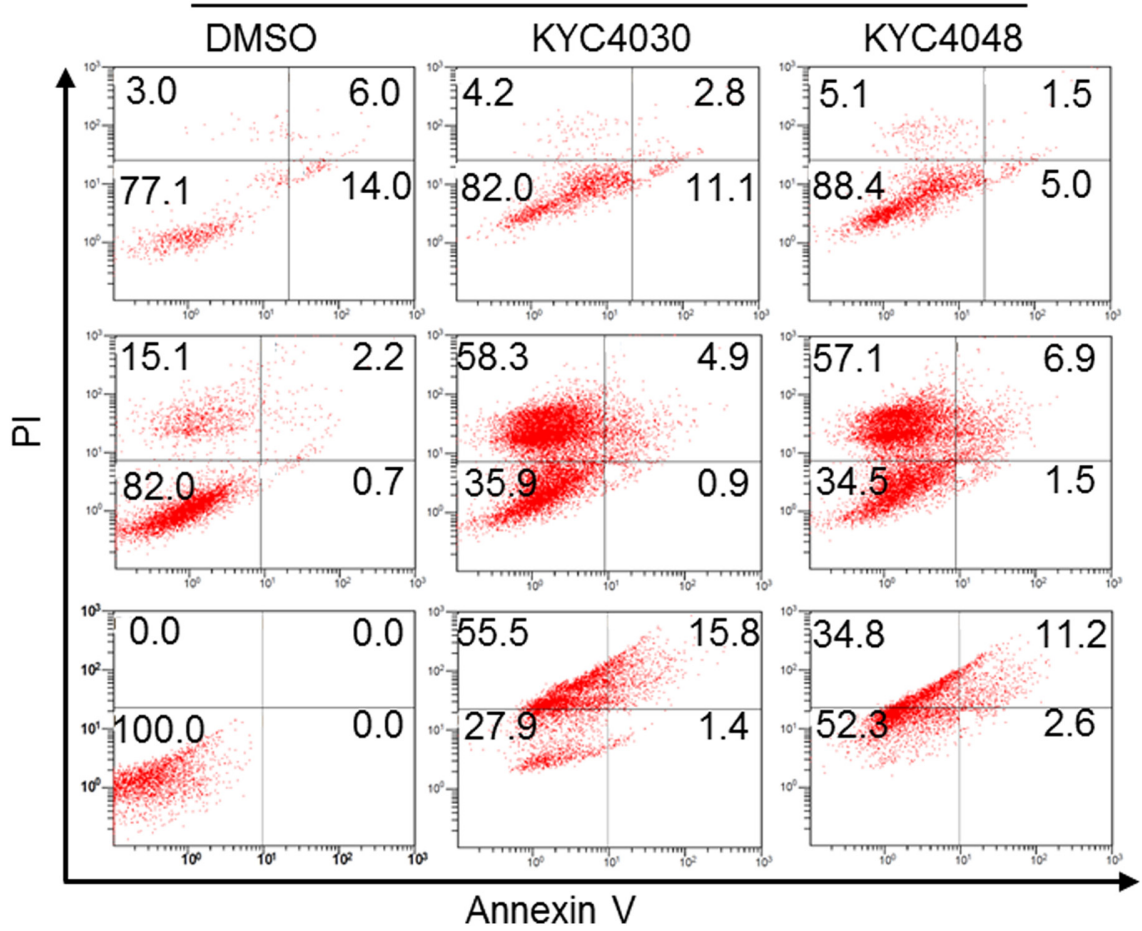

Normal Cells

(MCF10A)

Breast

Cancer Cells

(MCF7)

Neuroblastoma

Cells (SK-N-

$\mathrm{BE}(2)-\mathrm{M} 17)$

Fig. 3. Assessment of the DNA content and cell cycle in cells treated for $72 \mathrm{~h}$ with DMSO (control) or $200 \mu \mathrm{g} / \mathrm{ml} \mathrm{myxobacterial}$ metabolites, and stained with propidium iodide (A) or double-stained with Annexin V-FITC and propidium iodide (B). 
$4.08 \%$, and 5.2\%, respectively, in cells treated with KYC4048 metabolites. Similar changes were observed in brain tumor cells (Fig. 3A, bottom panels).

In normal cells treated with DMSO, and KYC4030 and KYC4048 metabolites and double-stained with annexin VFITC and PI, $77.1 \%, 82.0 \%$, and $88.4 \%$ were not apoptotic (Fig. 3B, top panels). However, the proportion of nonapoptotic cells was $35.9 \%$ and $34.5 \%$ in breast cancer cells exposed to KYC4030 and KYC4048 metabolites, and 82.0\% in those exposed to DMSO, suggesting that most cells had become apoptotic (Fig. 3B, center panels). Similar results were obtained in the brain tumor cells (Fig. 3B, bottom panels). Taken together, the data indicate that metabolites of myxobacteria did not affect the cell cycle or cell death in normal cells but induced cell cycle arrest and cell death in breast cancer and brain tumor cells.

\section{Breast Cancer-Associated Molecules Are Targeted by Myxobacterial Metabolites}

MCF7 breast cancer cells and MCF10 normal cells exposed

Table 2. Selected differentially expressed genes in MCF7 and MCF10A treated with KYC4048 metabolites.

\begin{tabular}{|c|c|c|c|c|c|}
\hline \multirow[b]{2}{*}{ Gene name } & \multirow[b]{2}{*}{ Annotation } & \multicolumn{4}{|c|}{ Gene expression level } \\
\hline & & $\begin{array}{l}\text { MCF10A } \\
\text { control }\end{array}$ & $\begin{array}{l}\text { MCF10A } \\
\text { treated }\end{array}$ & $\begin{array}{l}\text { MCF7 } \\
\text { control }\end{array}$ & $\begin{array}{l}\text { MCF7 } \\
\text { treated }\end{array}$ \\
\hline EGR2 & Early growth response 2 & 1.0 & 0.9 & 1.7 & 0.6 \\
\hline SEMA6C & $\begin{array}{l}\text { Sema domain, transmembrane domain, and cytoplasmic domain, } \\
\text { (semaphorin) 6C }\end{array}$ & 1.0 & 0.8 & 1.5 & 0.5 \\
\hline TAPT1-AS1 & TAPT1 antisense RNA 1 (head to head) & 1.0 & 0.5 & 1.7 & 0.4 \\
\hline$L A 16 c-313 D 11.12$ & Retained_intron & 1.0 & 0.5 & 2.1 & 0.4 \\
\hline CTD-2619J13.19 & & 1.0 & 0.7 & 3.2 & 0.8 \\
\hline ADAM32 & ADAM metallopeptidase domain 32 & 1.0 & 0.2 & 2.7 & 0.7 \\
\hline IFI27 & Interferon, alpha-inducible protein 27 & 1.0 & 0.1 & 3.1 & 0.3 \\
\hline POTEI & POTE ankyrin domain family, member I & 1.0 & 0.2 & 3.5 & 1.7 \\
\hline DHRS2 & Dehydrogenase/reductase (SDR family) member 2 & 1.0 & 0.5 & 34.6 & 12.9 \\
\hline KLK11 & Kallikrein-related peptidase 11 & 1.0 & 0.7 & 68.8 & 25.1 \\
\hline KIAA1324 & KIAA1324 & 1.0 & 1.7 & 47.4 & 18.6 \\
\hline TMEM64 & Transmembrane protein 64 & 1.0 & 0.8 & 20.9 & 8.9 \\
\hline SCUBE2 & Signal peptide, CUB domain, EGF-like 2 & 1.0 & 0.8 & 289.2 & 114.7 \\
\hline HMCN1 & Hemicentin 1 & 1.0 & 0.1 & 25.9 & 11.6 \\
\hline HLA-DRB1 & Major histocompatibility complex, class II, DR beta 1 & 1.0 & 0.8 & 762.3 & 321.5 \\
\hline GPER1 & G protein-coupled estrogen receptor 1 & 1.0 & 2.5 & 65.6 & 29.5 \\
\hline WNT2B & Wingless-type MMTV integration site family, member 2B & 1.0 & 1.9 & 5.6 & 1.9 \\
\hline PLXNA4 & Plexin A4 & 1.0 & 1.0 & 697.0 & 98.0 \\
\hline LINC01297 & Long intergenic non-protein coding RNA 1297 & 1.0 & 0.2 & 12.9 & 3.0 \\
\hline CLEC3A & C-Type lectin domain family 3 , member A & 1.0 & 0.0 & 155.9 & 32.8 \\
\hline LINC01522 & Long intergenic non-protein coding RNA 1522 & 1.0 & 1.0 & 326.0 & 73.0 \\
\hline LIMD2 & LIM domain containing 2 & 1.0 & 1.3 & 21.9 & 6.7 \\
\hline IGFBP5 & Insulin-like growth factor-binding protein 5 & 1.0 & 0.4 & 2073.0 & 552.1 \\
\hline LINC00494 & Long intergenic non-protein coding RNA 494 & 1.0 & 4.0 & 2414.0 & 642.0 \\
\hline RP11-68L18.1 & & 1.0 & 0.6 & 29.3 & 8.5 \\
\hline SUSD2 & Sushi domain-containing 2 & 1.0 & 0.7 & 31.8 & 9.7 \\
\hline
\end{tabular}


to DMSO or $200 \mu \mathrm{g} / \mathrm{ml}(1 \times)$ KYC4048 metabolites were analyzed by RNA sequencing to identify potential target genes or proteins affected by myxobacterial metabolites in cancer cells. In particular, we aimed to identify genes with differential expression patterns only in MCF7 cells treated with KYC4048 metabolites. Total RNA was extracted $24 \mathrm{~h}$ after exposure and 37,352 transcripts were analyzed. The number of reads was normalized and clustering was performed (Figs. S1 and S2). We selected 30 genes that were differentially expressed exclusively in breast cancer cells exposed to metabolites, compared with the same cells not exposed to KYC4048 metabolites or normal breast cells (w/o treatment, Fig. S1, Tables 2 and S2). In addition, total protein was extracted from MCF7 breast cancer cells treated with DMSO or KYC4048 and subjected to the Phospho Antibody Explorer Assay. Cancer-related genes with similar protein expression patterns as identified in RNA sequencing were then selected (Tables S3 and S4).

RNA sequencing and Phospho Antibody Explorer Assay indicated that the relative expression of the wingless family member $2 \mathrm{~B}($ WNT2B) gene and its downstream targets was decreased in MCF7 breast cancer cells exposed to KYC4048 metabolites. In cancer cells, WNT2B is activated and phosphorylates glycogen synthase kinase 3 beta (GSK3 $\beta$ ), inhibiting it. When not phosphorylated, GSK3 $\beta$ phosphorylates $\beta$-catenin and targets it for degradation. Therefore, WNT2B activation induces $\beta$-catenin stabilization and function and thereby regulates cancer cell survival [21]. The expression of WNT2B, phosphorylated GSK3 $\alpha / \beta, \beta$-catenin, and phosphorylated $\beta$-catenin was analyzed over time in breast cancer cells exposed to DMSO or KYC4048 metabolites (Fig. 4). WNT2B expression in the control and treated cells was comparable $24 \mathrm{~h}$ post treatment; however, its abundance decreased almost 2-fold at 48 and $72 \mathrm{~h}$ in cells exposed to KYC4048 metabolites, as measured by western blotting. Accordingly, the amount of phosphorylated GSK3 $\beta$ was decreased at $48 \mathrm{~h}$ post treatment. Both proteins diminished to a similar extent at $72 \mathrm{~h}$ in metabolites- and DMSO-treated cells. Both the phosphorylated and unphosphorylated forms of $\beta$-catenin were detected, with abundance fairly constant over time regardless of treatment. However, the abundance of phosphorylated $\beta$-catenin differed between DMSO- and KYC4048 metabolites-treated cells at $48 \mathrm{~h}$ post treatment.

\section{Discussion}

Myxobacteria are a source of potentially useful bioactive compounds. Of the 47 known species of myxobacteria,
S. cellulosum is the most studied, because its metabolites have high antibacterial and anticancer activities. In general, the entire genus Sorangium exhibits high anticancer activity $[3,22]$ and has accordingly attracted much attention, especially after the discovery of epothilone. Notably, we found that of all the isolated strains whose metabolites reduced cancer cell viability to less than $60 \%$, 11 were Myxococcus, two were Corallococcus, two were Sorangium, and one was Cystobacter (Table 1). The enrichment of Myxococcus instead of Sorangium might be determined by the metabolite extraction methods or by the environment from which the samples were collected.

Myxobacteria can be misidentified because of contamination or distortion of the fruiting body morphology. Therefore, we isolated, purified, and finally identified strains through repeated examination of the fruiting bodies and cell morphology, as well as by $16 \mathrm{~S}$ rRNA sequencing. Specifically, the Myxococcus strains KYC4030 and KYC4048 and Corallococcus strain KYC4081 were initially identified by fruiting body morphology; after their metabolites were found to have high anticancer activity and low cell toxicity, we confirmed their identity by $16 \mathrm{~S}$ rRNA sequencing. The strains were then cultured to obtain metabolites in amounts sufficient for subsequent experiments. As anticipated above, KYC4081 did not grow adequately under laboratory conditions, and only metabolites from KYC4030 and KYC4048 were characterized.

The metabolites investigated reduced the growth of

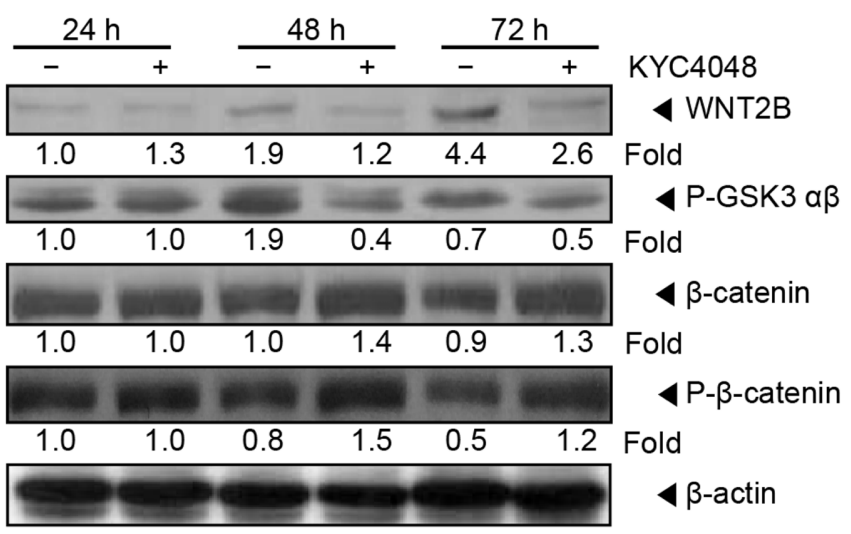

Fig. 4. Expression of WNT2B and its downstream target proteins.

MCF7 cells were treated with $200 \mu \mathrm{g} / \mathrm{ml} \mathrm{KYC4048} \mathrm{metabolites} \mathrm{or}$ DMSO for the indicated times. Cell lysates were resolved by sodium dodecyl sulfate-polyacrylamide gel electrophoresis and analyzed by western blot assay using antibodies against WNT2B, phosphorylated GSK $3 \alpha \beta, \beta$-catenin, phosphorylated $\beta$-catenin. $\beta$-Actin was used as a loading control. 
breast cancer cells in a dose- and time-dependent manner (Figs. 2A and 2C). The optimal concentration was determined as $200 \mu \mathrm{g} / \mathrm{ml}(1 \times)$, as the anticancer activity was negligible at $100 \mu \mathrm{g} / \mathrm{ml}(0.5 \times)$ and high toxicity was observed at $1,000 \mu \mathrm{g} / \mathrm{ml}(5 \times)$. Furthermore, we surmised that even though the anticancer activity at 200 and $400 \mu \mathrm{g} / \mathrm{ml}$ was comparable, the lower concentration would have fewer side effects. Notably, the metabolites isolated did not affect the growth of MCF10A (normal) cells, except at 1,000 $\mu \mathrm{g} / \mathrm{ml}$ (Figs. 2B and 2D). Conversely, cell growth was unaffected, or even enhanced, in normal cells treated with moderate amounts of myxobacterial metabolites. Taken together, the data suggest that the metabolites have minimal toxicity.

Fluorescence-activated cell sorting demonstrated that cancer cells treated with metabolites from KYC4030 and KYC4048 underwent cell cycle arrest and cell death (Figs. 3A and $3 \mathrm{~B}$ ), whereas normal cells did not. RNA sequencing was then used to identify genes or proteins specifically affected by the investigated metabolites in cancer cells. We selected 30 genes (Fig. S1, Table 2). The Phospho Antibody Explorer Assay was also performed to identify potential target proteins on the basis of phosphorylation status. We found that expression of the WNT2B gene and its downstream proteins was consistent with the RNA sequencing data (Table S3). In addition, western blot analysis showed that WNT2B expression was slightly lower at $48 \mathrm{~h}$ after exposure to the metabolites and was diminished almost 2-fold at $72 \mathrm{~h}$ (Fig. 4). Because WNT2B phosphorylates GSK $3 \alpha \beta$, the decrease in WNT2B was associated with the decrease of the phosphorylated form of GSK $3 \alpha \beta$. Both phosphorylated and unphosphorylated forms of $\beta$-catenin were detected, with abundance fairly constant over time. Because GSK3 $\alpha \beta$ phosphorylates $\beta$-catenin and targets it for degradation, the phosphorylated form of $\beta$-catenin increased when the expression of WNT2B and GSK $3 \alpha \beta$ decreased. We are aware that the differences in the abundance of these proteins were not extreme, perhaps because of the characteristic stability of the WNT pathway, which is only slightly perturbed, in contrast to other signaling pathways [21]. Nevertheless, WNT signaling has been shown to be involved in various cancer pathways [21], supporting the concept that its dysregulation may contribute to KYC4048 metabolite-mediated modulation of MCF7 breast cancer cell survival.

Finally, we observed that the growth of M. fulvus KYC4048 was more uniform in liquid medium compared to KYC4030 and the typical wild myxobacteria. This characteristic is advantageous for drug development, when large batches of the metabolite-producing strain need to be grown.
In summary, we found that metabolites of $M$. fulvus KYC4048 exhibited no toxicity in normal cells but specifically and substantially induced cancer cell death, potentially by suppressing the expression of WNT2B. This discovery highlights the value of assessing the metabolic and biomedical potential of myxobacteria newly isolated from novel environments, regardless of whether they were previously known to science, and the possible use of metabolites from KYC4048 in cancer treatments.

\section{Acknowledgments}

This work was supported by a grant from Kyung Hee University in 2016 (KHU-20160690).

\section{Conflict of Interest}

The authors have no financial conflicts of interest to declare.

\section{References}

1. Dawid W. 2000. Biology and global distribution of myxobacteria in soils. FEMS Microbiol. Rev. 24: 403-427.

2. Reichenbach H. 2005. Order VIII. Myxococcales, pp. 10591144. In Brenner DJ, Krieg NR, Staley JT, Garrity GM (eds.), Bergey's Manual of Systematic Bacteriology, 2nd Ed. Bergey's Manual Trust, East Lansing, MI.

3. Gerth K, Pradella S, Perlova O, Beyer S, Müller R. 2003. Myxobacteria: proficient producers of novel natural products with various biological activities - past and future biotechnological aspects with the focus on the genus Sorangium. J. Biotechnol. 106: 233-253.

4. Kim YS, Bae WC, Back SJ. 2003. Bioactive substances from myxobacteria. Korean J. Microbiol. Biotechnol. 31: 1-12.

5. Weissman KJ, Müller R. 2009. A brief tour of myxobacterial secondary metabolism. Bioorg. Med. Chem. 17: 2121-2136.

6. Gerth K, Bedorf N, Höfle G, Irschik H, Reichenbach H. 1996. Epothilons A and B: antifungal and cytotoxic compounds from Sorangium cellulosum (Myxobacteria). Production, physico-chemical and biological properties. J. Antibiot. (Tokyo) 49: 560-563.

7. Bollag DM, McQueney PA, Zhu J, Hensens O, Koupal L, Liesch J, et al. 1995. Epothilones, a new class of microtubulestabilizing agents with a taxol-like mechanism of action. Cancer Res. 55: 2325-2333.

8. Hyun H, Chung J, Kim J, Lee JS, Kwon BM, Son KH, et al. 2008. Isolation of Sorangium cellulosum carrying epothilone gene clusters. J. Microbiol. Biotechnol. 18: 1416-1422.

9. Stein A. 2010. Ixabepilone: providing new hope for women with breast cancer after anthracycline and taxane failure. 
Clin. J. Oncol. Nurs. 14: 65-71.

10. Lee FY, Borzilleri R, Fairchild CR, Kim SH, Long BH, Reventos-Suarez, et al. 2001. BMS-247550: a novel epothilone analog with a mode of action similar to paclitaxel but possessing superior antitumor efficacy. Clin. Cancer Res. 7: 1429-1437.

11. Fumoleau P, Coudert B, Isambert N, Ferrant E. 2007. Novel tubulin-targeting agents: anticancer activity and pharmacologic profile of epothilones and related analogues. Ann. Oncol. 18: v9-v15.

12. Schneiker S, Perlova O, Kaiser O, Gerth K, Alici A, Altmeyer MO, et al. 2007. Complete genome sequence of the myxobacterium Sorangium cellulosum. Nat. Biotechnol. 25: 1281-1289.

13. Wenzel SC, Müller R. 2009. The impact of genomics on the exploition of the myxobacterial secondary metabolome. Nat. Prod. Rep. 26: 1385-1407.

14. Ronning CM, Nierman WC. 2008. The genomes of Myxococcus xanthus and Stigmatella aurantiaca, pp. 285-298. In Whitworth DE (ed.), Myxobacteria: Multicellularity and Differentiation. ASM Press, Washington, DC.

15. Reichenbach H, Dworkin M. 1992. The Myxobacteria, pp. 3416-3487. In Balows A, Truper HG, Dworkin M, Harder W, Schleifer KH (eds.). The Prokaryotes, 2nd Ed. Springer Verlag, New York.
16. Shin H, Youn J, An D, Cho K. 2013. Production of antimicrobial substances by strains of myxobacteria Corallococcus and Myxococcus. Korean J. Microbiol. Biotechnol. 41: 44-51.

17. Lee C, Hyun H, Kim D, Cho K. 2009. Isolation of Chondromyces crocatus in pure culture. Korean J. Microbiol. Biotechnol. 37: 316-321.

18. Rainey FA, Ward-Rainey N, Kroppenstedt RM, Stackerbrandt E. 1996. The genus Nocardiopsis represents a phylogenetically coherent taxon and a distinct actinomycete lineage: proposal of Nocardiopsaceae fam. nov. Int. J. Syst. Bacteriol. 46: 1088-1092.

19. Spröer C, Reichenbach H, Stackebrandt E. 1999. The correlation between morphological and phylogenetic classification of myxobacteria. Int. J. Syst. Bacteriol. 3: 1255-1262.

20. Thompson JD, Higgins DG, Gibson TJ. 1994. CLUSTAL W: improving the sensitivity of progressive multiple sequence alignment through sequence weighting, position-specific gap penalties and weight matrix choice. Nucleic Acids Res. 22: 4673-4680.

21. Clevers H, Nusse R. 2012. Wnt/ $\beta$-catenin signaling and disease. Cell 149: 1192-1205.

22. Gerth K, Perlova O, Müller R. 2008. Sorangium cellulosum, pp. 329-348. In Whitworth DE (ed.), Myxobacteria: Multicellularity and Differentiation. ASM Press, Washington, D.C. 